\title{
2020 UF/IFAS Extension Industrial Hemp Permitted Acreage Report ${ }^{1}$
}

Matt Smith, Christian T. Christensen, and Zachary Brym²

\section{Industrial hemp cultivation returns to Florida}

The year 2020 marked the first time that commercial industrial hemp was legally grown in the state of Florida. After the passing of the 2018 Farm Bill and the United States Department of Agriculture's approval of the Florida Department of Agriculture and Consumer Services (FDACS) state hemp production plan on April 16, 2020, FDACS began approving the first cultivation permits for prospective growers on April $28^{\text {th }}$. By September $28^{\text {th }}$, FDACS had issued permits to over 500 businesses in the state with a combined footprint of over 21,000 acres (FDACS 2020a). That's nearly 33 square miles for Florida hemp. This publication is intended as a reference for permitted acreage in hemp for members of the Florida hemp industry, associated trades, and agencies.

\section{What is industrial hemp?}

Industrial hemp is legally defined as the plant Cannabis sativa $\mathrm{L}$. that has a total $\Delta-9-\mathrm{THC}$ concentration that does not exceed $0.3 \%$ on a dry-weight basis (FDACS 2020b). The chemical delta-9 tetrahydrocannabinol ( $\Delta-9$-THC) is the main psychoactive chemical found in cannabis and is responsible for the mood-altering "high." If a Cannabis sativa plant's THC concentration becomes greater than $0.3 \%$, it exceeds the legal limit for industrial hemp, and then may be defined as marijuana, an illegal Schedule 1 drug. By contrast, the average THC content of recreational marijuana in 2018 was $16.16 \%$ (DEA 2019).

\section{The Permitting Process}

Before starting an industrial hemp farm, prospective growers in Florida must obtain a hemp cultivation license through FDACS (https://www.fdacs.gov/Cannabis-Hemp/ Hemp-CBD-in-Florida). As part of the application process, growers must submit a copy of their fingerprints and prepare an environmental containment plan to mitigate escape from cultivation and invasion risk. They must also be aware of, and agree to comply with, the laws, regulations, and responsibilities associated with growing industrial hemp, including reporting crop harvests and submitting crop samples for THC testing.

\section{Industrial Hemp Cultivation Permits-Statewide}

From the opening of the permitting process at the end of April to the end of September 2020, FDACS approved 592 hemp cultivation permits. These permits went to 526 businesses overseeing 715 fields covering 13,200 acres. The average field size licensed was 18.5 acres. Prospective growers were quick to apply for licenses. 159 licenses (27\%) were approved during the first week, with over half of the

1. This document is SS-AGR-452, one of a series of the Agronomy Department, UF/IFAS Extension. Original publication date May 2021. Visit the EDIS website at https://edis.ifas.ufl.edu for the currently supported version of this publication.

2. Matt Smith, sustainable agriculture and food systems Extension agent, UF/IFAS Extension Sumter County, UF/IFAS Extension Pasco County, and UF/ IFAS Extension Hernando County; Christian T. Christensen, director and regional specialized agent, UF/IFAS Hastings Agricultural Extension Center; and Zachary Brym, assistant professor, Agronomy Department, UF/IFAS Tropical Research and Education Center; UF/IFAS Extension, Gainesville, FL 32611.

The Institute of Food and Agricultural Sciences (IFAS) is an Equal Opportunity Institution authorized to provide research, educational information and other services

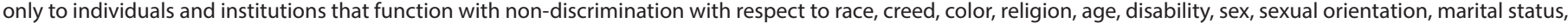

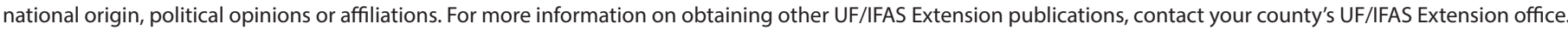
U.S. Department of Agriculture, UF/IFAS Extension Service, University of Florida, IFAS, Florida A \& M University Cooperative Extension Program, and Boards of County Commissioners Cooperating. Nick T. Place, dean for UF/IFAS Extension. 
year's licenses in this period approved by May 27th, just one month into the program. While the April period may seem small, keep in mind that it only covers the last three days of the month.

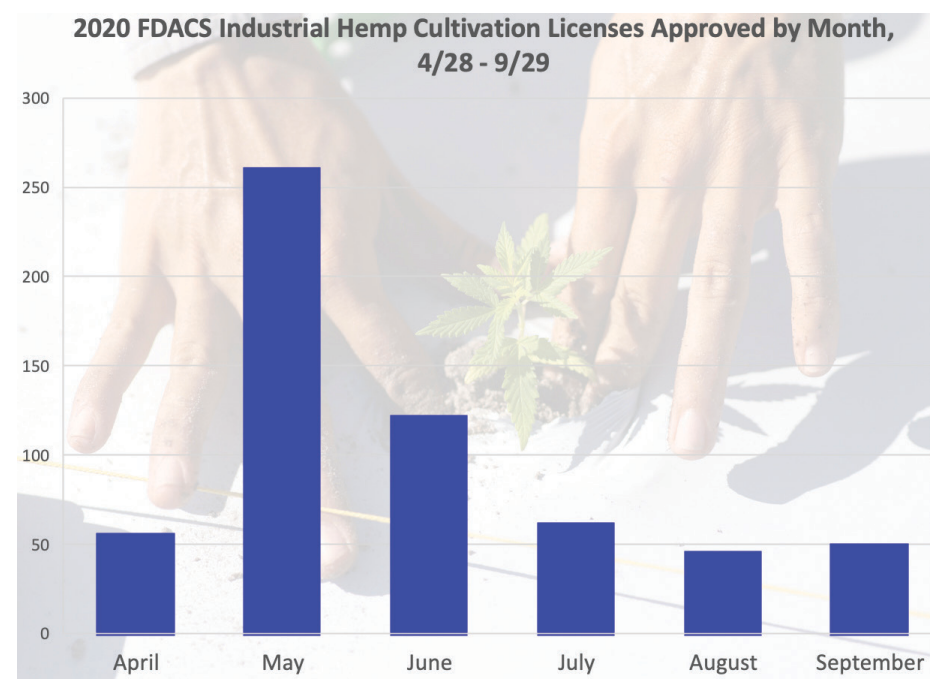

Figure 1. FDACS hemp cultivation licenses by month. Background Photo: Industrial hemp trial seedling being planted. Photo taken 0720-20.

Credits: Tyler Jones, UF/IFAS

\section{Industrial Hemp Cultivation Permits-By County}

Industrial hemp cultivation permits were issued in 2020 to businesses in every county in Florida. The county with the largest total acreage was Hendry County with 7,806 acres, followed by Miami-Dade County $(2,974)$, Palm Beach County $(1,142)$, Suwannee County $(1,099)$, and Broward County $(1,072)$. This land represents the diversity of agricultural operations across Florida with farmers permitting land previously in citrus, row crops, turf, ranchland, and forestry. The county with the largest number of permitted industrial hemp farming businesses was Miami-Dade County with 68, followed by Palm Beach County (32), Alachua County (26), Orange County (26), and Hillsborough County (23). Businesses may own and cultivate multiple fields and are required to list the acreage of each field they intend to cultivate. Miami-Dade County claimed the highest number of permitted fields with 95,

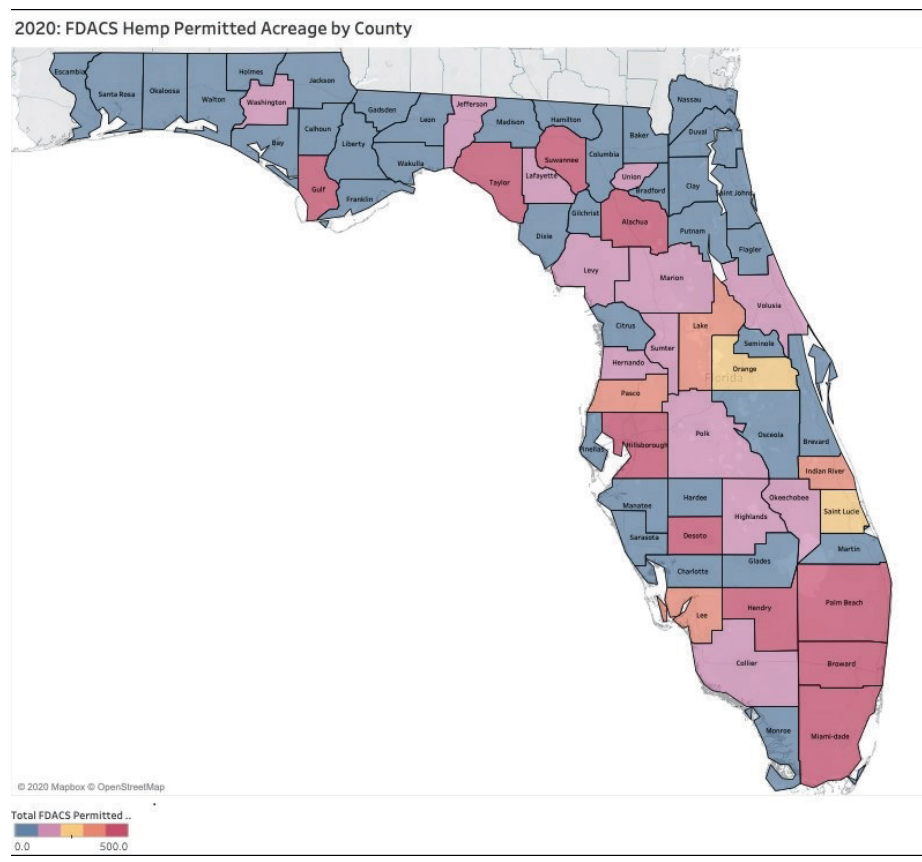

Figure 2. FDACS permitted hemp acreage by county. Colors depicted in the figure legend represent change in 100-acre increments. The lowest percentile (blue) represents counties with business addresses where the sum of permitted acreage is between 0 and 100 acres. The top percentile (red) represents counties with business addresses where the sum of permitted acreage is greater than 400 acres. Credits: Christian T. Christensen, UF/IFAS

followed by Orange County (42), Hillsborough County (38), Palm Beach County (37), and Broward County (36).

\section{Industrial Hemp Cultivation Permits-By UF/IFAS Extension District}

The UF/IFAS Extension system divides the state into five regional districts: Northwest, Northeast, Central, Southwest, and Southeast.

The Southeast District holds by far the largest amount of industrial hemp license activity in the state, leading in the total permitted acreage $(14,130)$, the number of permitted industrial hemp farming businesses (177), and the total number of fields (266). The Northeast District ranks second in total permitted acreage $(2,584)$ and fourth in both hemp farming businesses (83) and total number of fields (105). The Southwest District ranks third in permitted acreage $(2,410)$, hemp farming businesses (108), and total number of fields (158). The Northwest District ranks fourth in total permitted acreage $(1,281)$ and fifth in hemp farming businesses (54) and total number of fields (68). Finally, the Central District ranks fifth in total permitted acreage $(1,266)$ but ranks second in hemp farming businesses $(123)$ and total number of fields (164). 
If we look at the average number of permitted acres per licensed hemp farming business, the Southeast District again takes the lead (80), followed by the Northeast District (31), the Northwest District (24), the Southwest District (22), and the Central District (10). Hemp grown for different purposes, such as fiber or CBD oil, requires different

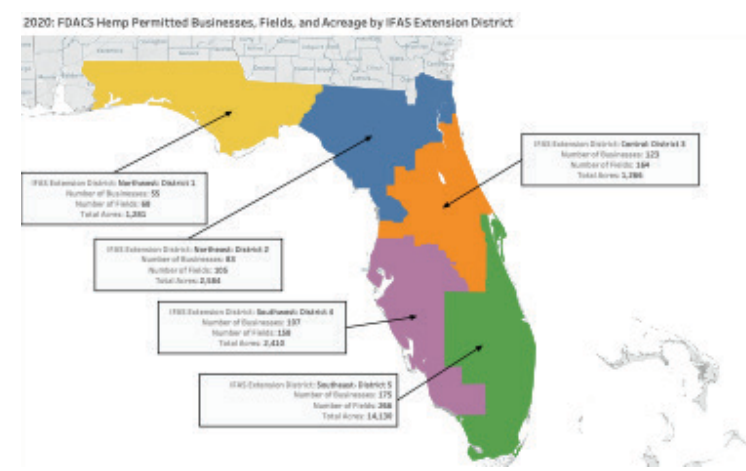

Figure 3. Map of FDACS hemp permitted businesses, fields, and acreage by UF/IFAS Extension district.

Credits: Christian T. Christensen, UF/IFAS

acreages to achieve profitability (Mark et al. 2020), so acreage per business should not be interpreted as a way to infer the expected revenue for farms in each district.

\section{Into the New Year}

The success of the inaugural FDACS industrial hemp cultivation permitting process has proven that there is a real, tangible interest among Floridians to grow hemp as a new alternative crop. From Pensacola to Homestead, growers completed all required steps and submitted themselves to regulatory inspection to ensure that their fields would be legally compliant. While the prospects are exciting, widespread industrial hemp profitability remains unproven, and growers must accept the risks associated with the operation. Considering hemp is a new crop for
Florida producers, continued research and outreach will prove to be invaluable for further investigations of hemp as an economically viable alternative and emerging crop for production across Florida.

\section{References}

DEA. 2019. 2019 Drug Enforcement Administration National Drug Threat Assessment. https://www.dea.gov/sites/ default/files/2020-02/DIR-007-20\%202019\%20National\%20 Drug\%20Threat\%20Assessment\%20-\%20low\%20res210.pdf

FDACS. 2020a. "Hemp/CBD in Florida." Accessed on May 13, 2021. https://www.fdacs.gov/Cannabis-Hemp/ Hemp-CBD-in-Florida

FDACS. 2020b. "Florida Administrative Code Rule 5B-57.014 - State Hemp Program." Accessed on May 13, 2021. https://www.fdacs.gov/content/download/91558/file/ rule-5b-57.014.pdf

Mark, T., J. Shepherd, D. Olson, W. Snell, S. Proper, and S. Thornsbury. 2020. Economic Viability of Industrial Hemp in the United States: A Review of State Pilot Programs. EIB217. U.S. Department of Agriculture, Economic Research Service. 